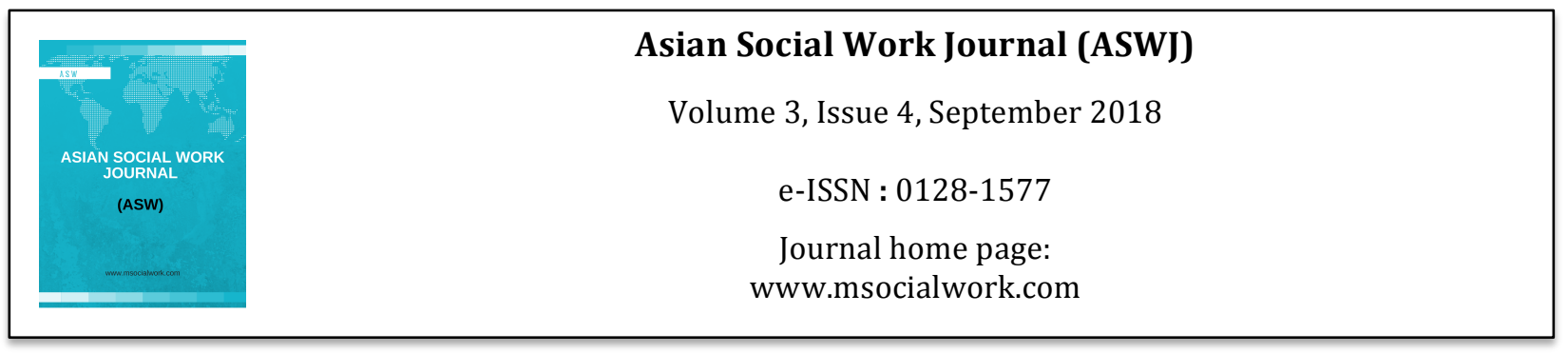

\title{
Improving the Life of Former Female Migrant Domestic Workers
}

\author{
Rosita Tandos ${ }^{1}$ \\ 1State Islamic University of Syarif Hidayatullah
}

Corrrespondence: Rosita Tandos (rosita_tandos@yahoo.com.au)

\begin{abstract}
Some studies exploring the life of migrant domestic workers found that the main factor that push Indonesian migrant domestic workers is experiencing severe economic condition (Raharto, 2000; Silvey, 2004; Pitoyo, 2007). The poor economic condition forces women and girls to be domestic workers. Additionally, cultural value of patriarchy puts a responsibility for women at domestic area influencing the women's ability to fill the demand of the domestic workers in overseas. This paper addresses the main topic of enhancing protection and empowerment for Indonesian female migrant domestic workers by specifically exploring the issues after working in overseas. The study exploring the life of former migrant domestic workers from Bondan village of Indramayu district using qualitative method. The informants of the study were the workers who just finished their work contract, staying at the moment in the village waiting for the next call or deciding to stop working in overseas. The number of participants was 40 women $(n=40)$, joining focus-group discussions and in-depth interviews. The theoretical frameworks used in the study consist of human capabilities approach, feminist perspective, and social work theories of empowering individual, family, and community. Then, the discussion covers three main points: first, discussion of the theories applied in the study; second, the life of transnational domestic workers of examining abusive conditions; third, developing future practices to empowering the workers; and fourth, a part of the paper provides conclusion to whole points discussed.
\end{abstract}

Key words: female migrant domestic workers, issues of transnational domestic work, empowerment

\section{Introduction}

Globalization creates global market and mechanisms of transnational domestic work. At this point, the product 'sold' is human who force to leave their countries seeking for better income. Silvey (2004) explained that structural processes affect women's migration. Female migrant workers from South and/or Eastern Asia tend to be channeled into certain types of work within low-paying and low-skilled service sector jobs.

Raharto (2002) added that migrant workers are motivated by factors such as the availability of promising jobs, the existence of social capital created by relatives and/or friends who migrated earlier, the encouragement of local agents or middlemen or recruiters' influences, and the desire to gain a higher social status.

Data from the Ministry of Manpower and Transmigration of the Republic of Indonesia (Kementerian Tenaga Kerja dan Transmigration) shows that in 2002, 94 percent of legal Indonesian female migrant workers served as domestic workers in the Middle East, East Asia and Southeast Asia. In Malaysia, 
one of the main destination countries, 90 percent of the approximately 240,000 domestic workers are Indonesian. If this number is added to the number of people who migrated illegally, the final figure could easily be doubled. It is mainly Indonesian females who are hired for domestic work, and the services they provide are vital to those employing migrant workers (Indonesian Human Right Watch, 2005).

Another issue in dealing with transnational domestic work is human trafficking. Hardani and colleagues (2004) define human trafficking as "movement of persons (especially women and children), with or without their consent, within a country or internationally, for all forms of exploitative labor, not only prostitution and servile marriage" (cited in Kimura, 2006, p.8). Trafficking people has been embedded in the market of transnational migrant workers under the modern capitalist system (Kimura, 2006).

In addition, many female domestic workers are often under-protected and disempowered. Some studies have investigated these phenomena (Anggraeni, 2005; Novirianti, 2009; Raharto, 2002; Silvey, 2001). However, these studies do not systematically capture the risk factors that affect the Indonesian women's decisions to work overseas and the processes of working domestically overseas. Prior studies also do not provide a comprehensive analysis of transnational domestic work stages, protection and empowerment policies and programs at national and international levels. This proposed study aims to discuss and analyze these points.

\section{Theories in Use}

This paper applies two main theories of social work perspectives (feminist in social work and empowerment). First, using feminist theory is significant since other studies of paid domestic laborers have examined the ways in which class, race, ethnicity and nationality figure in household divisions of labor (Heyzer et al., 1994; Hondagneu-Sotelo, 2001; Huang \&Yeoh, 1996; Radcliffe, 1990). The main solution, according to a feminist perspective, is providing more spaces for female migrant workers to tell their stories, listen to their voices, and reconstruct the stories, validate their analyses of situations and engage them in decisions about their lives (Dominelli and McLeod, 1989; Hanmer and Statham, 1998). Then, empowering migrant female domestic workers means to help them gain control of their lives that would challenge patriarchal arrangements, evaluate interventions, and alleviate oppressive activities in light of their impact on the oppression of women.

Second, empowerment theory in social work perspective is considered an ideal understanding of transnational domestic workers since there is a need for systematic and comprehensive interventions to facilitate empowerment at both individual and institutional levels. At this point, empowerment is defined as a process of changing power relations in favor of those at the lower levels of a hierarchy; through this process, access to and control over resources are increased (Presser and Sen, 2000; Inaba, et al., 2001), followed by a dynamic continuum of action from individual and small group development to community organization, partnership and advocacy or political action (Rissel, 1994).

Social workers use the empowerment framework to help oppressed groups to gain power and authority and to pursue the fulfillment of their intervention goals (Lee, 1996; Maton \& Saleem; 1995; Rappaport, 1987). In addition, social workers use this approach to relieve clients of economic, social, and personal privation by relocating power from the environment and systems. In this regard, clients develop the capacity and self-confidence to make decisions and take actions in their own lives (Feste \& Anderson, 1995; Gibson, 1991; Payne, 2005).

Female migrant domestic workers often follow what has been dictated to them, such as the decision to go overseas, their job description, and their work obligations. Such power inequality maintains insecurity in the lives of these women. Dominelli $(2000,2002)$ mentioned that understanding and analyzing power relations are essential to feminist theorizing of oppression and developing alternative ways that eliminate the privileging of one group over others. 
Empowerment programs that have been set up for foreign domestic workers might consider the psychological aspect (increasing cognitive, emotional, behavioral and relational capacities) of empowerment. These psychological aspects can be acquired through the women's participation in collaborative empowering community settings, particularly in efforts to change collectively social and political systems (Christens et al., 2012). Through this process, women are expected to develop their involvement as active learners, leadership, interpersonal relationship and networks, and develop a belief in their own ability to have an impact on those systems (Christens, 2011, 2012).

Finally, a genuine collaboration with all stakeholders is another crucial point for effectiveness, efficiency and sustainability of the policies and programs (Carigi, et al., 2005; Smith \& Esim, 2004; Lawson, 2001). This collaboration is necessary to achieve desirable outcomes and make fundamental change. In addition, it is important to address multiple dimensions of transnational domestic work.

\section{Downsides of Being Transnational Domestic Workers}

Another side of the life of migrant domestic workers is experience of abusive conditions, as one of the negative sides of transnational work. In fact, some of female migrant domestic workers still come back home with physical injury/ies. The National Agency for Placement and Protection of Indonesian Workers (BNP2TKI) in 2012 reported that 328 female migrant domestic workers died overseas, with their bodies being returned home. The domestic workers are trapped in the power dynamics between the sending and receiving countries (Piper, 2004).

Female domestic workers experience similar negative repercussions in a variety of other countries, Parrenas (2005) illustrates reasons why women from the Philippines work overseas, serving households and their nation. Their situation is maintained by structural oppression as experienced by other East Asian domestic workers. In addition, Jureidini and Mourkarbel (2004) described the life of Sri Lankan female domestic workers who experience a lack of freedom along with the necessity of earning money for their families back home. Such conditions render them extremely vulnerable to abuse and exploitation. Three types of abuses (verbal, physical and sexual) has examined by the participants living at Bondan village. Verbal abuse was mostly examined by the women in form of yelling to them or calls them with 'animal' names. The women worked over hours and did not have time to meet others outside the employers' home.

In addition, agent in overseas (who did placement to the workers) did not pay attention to the women. Therefore, once the women faced a problem, they just pray to God or escape from their employers' home when they get abused. For those who know the location of Indonesia Embassy office, they would go there asking for protection.

For years, the injustice and human rights' violations experienced by female domestic workers have been a concern for national and international organizations. As a result, a number of foreign and migration policies have been changed to overcome the problems. At the international level, the concerns for worker rights began with the founding of International Labor Organization (ILO) in 1919. The ILO conference adopted the convention concerning decent work for domestic workers and a recommendation supplementing it, referred to as the Domestic Workers Convention (No.189) and Recommendation (No.201). These two instruments produced in 2011 by the ILO contain specific standards and minimum protection for domestic workers.

Riker (1998) explained that NGOs in Indonesia have existed since the 1980s where they network and share experience, take collective actions, and express their concerns and interests. The development of these networks and coalitions has been extremely important for political change (as cited in Breton, 2004 p.6). Therefore, efforts aiming to protect the female workers' rights should be able to develop the women's capabilities and emphasize collaboration between sending and receiving countries. 


\section{Enhancing Future Actions}

During data collection process, the participants from Bondan village mentioned four main recommendations regarding the need for protection and empowerment for female migrant domestic workers. Most of the women do not want other women and girls of their families and communities to be migrant domestic workers and examined risky and hard lifetime in overseas. They emphasized the need for sufficient knowledge and skills to support their work in overseas, and the importance of law enforcement for agencies (at home country and host country) if they ignore the workers' rights.

This study highlights the two points of protection and empowerment and develops some recommendations that are relevant to social work interventions at the micro, mezzo and macro levels. They include: 1) developing individual capabilities, 2) empowering families and communities, and 3) enhancing partnership between sending and receiving countries.

\section{Developing individual capabilities of the workers}

The first area to focus for protecting and empowering migrant domestic workers should happen in the sending country. As mentioned previously, the workers should be provided with a comprehensive training program that not only combines the knowledge and skills, but also the women do not need to pay more for the training session before leaving abroad.

Moreover, providing work training and a pre-departure orientation would provide a significant positive impact on the development of domestic workers' capabilities. If resources are a concern, some studies suggest that a placement test should be applied prior to the training session to decide what training level a prospective migrant domestic worker should enroll in and the length and the level of training needed to cope with daily work issues (Azmy, 2012; Irianto, 2011; Varia 2008).

The ability of the workers - to understand, adjust, and anticipate certain unpredictable and unexpected circumstances- is one of the points of human capabilities approach that might applied to the domestic work context. Therefore, the training sessions should address the needs of the domestic workers, including essential legal information, particularly in terms of sponsors and agents, working conditions, the workers' rights and responsibilities, and where to seek assistance in cases of difficulties or crises (Orange, et al., 2012). According to Briones (2008), any efforts that aim to protect the domestic workers' livelihood can create opportunity and develop capabilities for securing the worker's rights.

In terms of placement and signing the contract, the women from Bondan village suggested that they should be allowed to choose the country of work. They should also have the opportunity to understand all of the points in the contract without other people's influence or manipulation. Additionally, the ILO (2009) suggested that the migrant workers should be provided with a legal contract, responding the point of safe and health working condition.

The final suggestion is an effort to empower and support the returned migrant domestic workers to overcome any issues after returning back home. From the participants of this study, the major issues are financial including having unpaid debt or new debt. The participants suggested that the governmental and other institutions that are concerned with the issue of transnational domestic work are expected to provide the women with knowledge, skills and capital (funds) to open a new business. Therefore, a program such as community economic development (CED) programs might be a viable solution for the financial issues many former workers experience when they return back home.

The CED program could provide funds that the women could be borrowed and also help the women to develop knowledge about entrepreneurship and small business management. Such programs could also develop the women's leadership and teamwork skills as they support each other. It also should emphasize that the success of the program's participants and the model of economic empowerment might be used with others who examine similar issues of transnational domestic work business at Bondan village or other places in Indonesia. 
Christens et al. (2012) confirmed that a sense of collectiveness is one option and work by improving women's participation in collaborative community settings, and suggested it may also be able to change systems socially and politically. Thus, developing the women's capabilities through community economic development program that provide an opportunity for the women to access capital to have their own businesses. In addition, learning how to run a small business or home-based industry might be a way to empower domestic worker groups, supporting the women to as they strive to continue contributing financially to their families.

The former female migrant domestic workers also might have an opportunity to reflect on their experiences and share their successes with others that could bring a positive effect to themselves, their groups and the whole community. Additionally, the women could enhance their capabilities by creating unions or 'Paguyuban' a community based-organization to channel their voices and interests (Dominelli, 2000, 2002).

By implementing such community economic empowerment programs, the women's capabilities and self-efficacy could be improved, affecting their decisions and actions for a better future (Cattaneo and Chapman; 2010; Zimmerman, 2000). Then, incorporating a human capability approach means that the domestic workers' unions might have an integrated programs that help improve their members' capabilities, such as language development, work skills, and sharing and learning experience from one another. These efforts might improve the women's personal and collective capabilities and increase accessibility to assets, resources, and support systems.

\section{Empowering family and community}

As mentioned previously, a major issue faced by the domestic workers when they returned from working overseas is the women's relationships with their husbands and families. Marriage became a concern of the domestic workers when they returned home. In addition, the participants from Bondan village said that their families had a significant role in cultivating the women's resilience to face daily issues. Therefore, a cooperation with the families' domestic workers and their husbands may diminish the issues.

Additionally, village leaders, and community figures should be involved in addressing issues faced by the women and their families, as they are among strategic parties. They could work together to address any issues emerging throughout all the stages of transnational domestic work. They could work together to 'control' the recruitment process that currently harms the women's lives particularly in terms of illegal sponsors and agents (ILO 2009).

With such supports, the women might be able to manage the remittances, use the money for future investments, and address the various issues when returning back to families and communities. Furthermore, bilateral and multi-lateral coordination and partnership among countries could improve the protection and empowerment of transnational domestic workers. Then, the next section focuses on improving cooperation between sending and receiving countries to address the various challenges of transnational domestic work.

\section{Improving partnerships of sending and receiving countries}

Both sending and receiving countries have to work together in order to respond to and address all of the issues and risks of transnational domestic work. Their combined efforts could create a significant positive impact on the health and safety of the women while they are working overseas. The following discussion focuses on suggestions for enhancing the coordination between and partnerships among the governments, specifically managing the recruitment processes and addressing issues while the women are working overseas.

The first stage of transnational domestic work is the recruitment process conducted in both home and host countries involving the recruitment agents who are working in both countries (Heyzer, 2006; Varia 2008). The mechanism of supply and demand needs a bilateral coordination and partnership 
involving players in both sending and receiving countries (Esim \& Smith, 2004; Heyzer 2006; ILO 2006, 2009). According to the ILO (2009), origin countries should cooperate with destination countries in order to control the implementation of the employment contract. At this point, agents in the home country and all stakeholders should work together to provide sufficient information about all aspects of migrant work, such as any fees required to obtain the job, the migration process, and the actual terms and conditions of working in the host country.

However, these suggestions have not been fully implemented as yet. Cooperation among some governmental institutions in Indonesia has not effectively ensured a system of exporting labor that respect human rights (Solidaritas Perempuan, 2015). As a result, the women's rights are often violated. Regarding their victimization by irresponsible sponsors and unscrupulous private recruitment agents, many participants living in Bondan village suggested and insisted that there should be a strict punishment for parties who violate the rights of the migrant domestic workers. The women suggested that the punishment might be in the form of legal punishment and/or closing their offices and practices.

The next issue with the current systems (or lack of systems) between countries is related to the employment contract. In this case, the contract is useless when the receiving countries are reluctant to enforce the standards of the employment contract. Additionally, the failure of the host country can be seen from the fact that most of the agreement is made by the foreign agent and tend to mostly reflect the interests of employers (Heyzer, 2006; Hugo, 1995; Raharto, 2002; Sukamdi, et al., 2007; Yazid, 2008).

However, some countries have made significant efforts to improve protections for domestic workers. In Hong Kong and Taiwan, domestic workers can complain to the Labor Court if their employers do not pay their salaries. Then, the Court can order their employers to pay the salary of the workers. If the employers do not do so, they can be sent to jail (Anggareni, 2006). This is a good example of how the government of a sending country can enhance the coordination and cooperation with the receiving country to ensure their workers' rights are protected and make efforts to empower workers.

The last issue of empowerment is concerned with policies and programs available for the domestic workers. The improvement of both policies and programs - in all stages of transnational domestic work- should take into account the women's voices and stories, respond to their needs and interests, and engage them in decisions about their lives (Dominelli and McLeod, 1989; Hanmer \& Statham, 1998). Listening and understanding the domestic workers' aspirations could help shed more light on the problems and lead to solutions.

To stand by the workers' side is a crucial step to establish commitment and sustain the improvement of programs and services. Applying intersectionality perspective can explore the intersection of discriminations in terms of age, race, gender, class, and other variables of transnational domestic work. Then, the perspective requires descriptions and analysis to adequately address the domestic workers' rights, especially for the transnational domestic workers (Satterthwaite, 2012).

Furthermore, prevention programs could anticipate and eliminate the dangers and risks that the workers may face. The programs could also be used to inform and educate prospective workers on how to migrate to protect their rights as workers (Azmy, 2012; BNP2TKI 2014, Silvey, 2004). In this case, agents in the home and host countries would be required to write a contract that explains the worker's rights, and this could minimize certain risks (ILO, 2009).

Consciousness-raising programs could be conducted between those who experienced working domestically in overseas. In feminist perspective, such program could be more effective when people or the women could share the same oppression that they examined (Howe, 2009). Additionally, awareness-raising programs and public campaign involving all stakeholders might also be alternative programs to empower the women and communities (Dominelli, 2002).

Such prevention programs could tackle the stereotype of domestic work being part of the 3D sector (difficult, dirty and dangerous) (Azmy, 2012; Piper, 2004; Varia 2010). Lastly, an effort of reformation 
or change to the migrant labor system must ensure that migrant workers have 'decent work'. In the ILO's (2006) terms, this means 'productive work' with conditions of freedom, equity, security, and dignity. Of course, improving international legal protection that bind all parties involved in this multibillion dollar business should be applied simultaneously and seriously.

Novirianti (2010) and Silvey (2004) confirmed that cooperation among local, national, and international bodies is needed to address structural problems through producing and implementing policies that reflect the needs and interests of Indonesian female domestic migrants. In Asia, NGOs and community-based organizations (CBOs) have initiated the first step for immigration cooperation. Furthermore, collaboration between academics, NGOs, and individual migrants aims to improve the condition of migrant workers and protective legal mechanisms.

Therefore, key strategic groups and stakeholders should be involved in all of the efforts. Valuing the women's' perspectives on all of the issues - the domestic workers experienced prior, during, and after working overseas- has important implications for future improvement of policies, programs and services. Such efforts could support the implementation of local and national laws and regulations, as well as international laws, including the ILO and UN conventions and treaties.

\section{Conclusion}

In conclusion, this study shows that a comprehensive understanding of transnational domestic workers as an important step to addressing the issues and creating fundamental changes. Applying qualitative method was an effective method for exploring the issues and topics in depth. It was also a means for the women to raise their voices and share their thoughts about the issues they experience doing this work. The theoretical frameworks of the capabilities approach, intersectionality, empowerment, and feminist social work enhanced the analysis of the problems, solutions developed for changing policies, and improving programs and services.

The discussions include factors with the six stages of the work, the impacts on the women's lives, and suggested solutions for the problems faced by the women while working abroad. These three points are important to consider when trying to determine the roles of states, families, and other stakeholders of the foreign domestic work business.

The six stages of migrant domestic work include the recruitment process, the training program, placement and signing the contract, working overseas, finishing the contract, and returning back to the home country. The challenges begin at the first stage of the recruitment process. With the involvement of sponsors (middle-men) that have closed relationship with the women and communities, the opportunity for working abroad still continues.

The women participating in transnational domestic work are the main actors in this enterprise, as such that their capacity and capabilities should be developed so that they can live and work in healthy and safe circumstances, respecting their rights as workers. The solutions raised from the women's perspective might be integrated for future efforts at policy change and improvements of program and services available for the domestic workers.

Therefore, the improvement of the helping profession practices should take into account the rights and the development of the capabilities of the domestic workers. All efforts should be conducted systematically and effectively local, national, and international levels. In addition, partnership and coordination among stakeholders are necessary to ensure and enhance protection and empowerment for the domestic workers. 


\section{References}

Agrawal, A. (2006). Migrant women and work (women and migration in Asia). New York: Sage Publication

Albin, E. \& Mantouvalou, V. (2012). The ILO convention on domestic workers: From the shadows to the light. Virginia: UCL Labor Rights Institutes

Alkire, S. (2005). Why the capability approach?. Journal of Human Development, 6, 115-133

Anggraeni, D. (2006). Dream Seekers: Indonesia Women as Domestic Workers in Asia. Jakarta: Equinox Publishing

Bacchus, N. (2005). The effect of globalization on women in developing nations. New York: Pace University Press

Bell, D. \& Piper, N. (2005). Justice for migrant workers?The case of foreign domestic workers in Hong Kong and Singapore. In Kymlicka, W. \& He, B. (eds), Multiculturalism in Asia. Oxford: Oxford University Press

Cattaneo, L.B., \& Chapman, A. (2010). The process of empowerment: A model for use in research and practice. American Psychologist, 65(7), 646-659

Clark, A.A. (2005). Sen's capability approach and the many spaces of human well-being. The Journal of Developmental Studies, 8, 1339-1368

Creswell, J.W. (2009). Research design: Qualitative, quantitative and mixed methods approaches. United Kingdom: Sage Publication.

Dominelli, L. (2002). Feminist social work theory and practice. New York: Palgrave Macmillan

Ehrenreich, B., \& Hochschild, A.R. (2004).Global women: Nannies, maids, and sex workers in the new economy. Canada: Owl Books

Esim \& Smith, (2004). Gender and migration in Arab States: The case of domestic workers. Retrieved http://www.ilo.org/public/english/region/arpro/beirut/.../publ 26 eng.pdf

Healey, K. (2005). Social work theories in context: Creating framework for practices. New York: Palgrave Macmillan

Heyzer N., \& Nijeholt G.L.A \& Weerakoon, N. The trade in domestic workers: Causes, mechanisms and consequences of international migration. International Review of Victimology: Zed Books

Howe, D. (2009). A brief introduction to social work theory. New York: Palgrave Macmillan

Hugo, G. (2000). Migration and women's empowerment, in Presser \& Sen (eds)., Women's empowerment and demographic processes: Moving beyond Cairo. New York: Oxford University Press

Ife, J. (2001). Human rights and social work: Towards rights-based practice. Australia: Cambridge University Press

International Labor Organization. (2004). Gender and Migration in Arab States: the Case of Domestic Workers. Beirut: Regional Office for Arab States

International Labor Organization. (2009). Protecting the rights of migrant workers: A shared responsibility. Geneva: ILO

Jureidini, R. \& Mourkarbel, N. (2004). Female Sri Lankan domestic workers in Lebanon: A case of 'contract slavery'?. Journal of Ethnic and Migration Studies, 30, 581-607

Kimura, K. (2006). Human Trafficking in Indonesia: Rethinking the New Order's Impact on Exploitative Migration of Indonesia Women. Ohio University: The Center of International Studies

Lawson, H.A. (2001). Introducing globalization's challenges and opportunities and analyzing economic globalization and liberalization. In K.B. Lawson, H.A. Lawson, C.B. Hennon, A.R. Jones, Family-centered policies and practices

Loveband, A. (2003). Positioning the product: Indonesian migrant women workers in contemporary Taiwan. Working Papers Series, 43, 1-15

Lyons, L. (2006). The limits of transnational activism: organizing for migrant workers rights in Malaysia and Singapore. Paper presented for the Workshop 'Transnational of Solidarities and Women Movements', Universite de Montreal, April 27-28, 2006

McGovern, L.L. (2009). Neo-liberal globalization in the Philippines: Its impact on Filipino women and their forms of resistance. Indiana University: Political Science

Moniaga, R. (2008). Indonesian migrant domestic workers. GPIA: The New School Graduate Program in International Affairs 
Novirianti, D. (2009). Female Migrant Workers and Access to Justice. Retrieved from http://www.media.leidenuniv.nl/.../femalemigrantworkers-access tojustice

Nussbaum, M. (2000). Women and human development. Boston: Cambridge University Press

Orange, G., Seitz., V., \& Kor, A.L. (2012). Information dissemination needs of Indonesian migrant domestic workers in Malaysia. Journal of Southeast Asian Research, 2012, 1-16

Parrenas, R.S. (2005a). Long distance intimacy: Class, gender, and intergenerational relations between mothers and children in Filipino transnational families. Global Network, 5, 317-336

Piper, N. (2003). Bridging gender, migration and governance: Theoretical possibilities in the Asia context. Asian and Pacific Migration Journal, 12, 21-48

Piper, N. (2004). Gender and Migration Policies in Southeast Asia and East Asia: Legal Protection and Socio-Cultural Empowerment of Unskilled Migrant Women. Canberra: the Australian National University

Pyles, L. (2009). Neoliberalism, INGO practices and sustainable disaster recovery: a post-Katrina case study. Oxford University Press and Community Development Journal, 1-13, doi:http://10.1093/cdj/bsp058/2009

Raharto, A. (2002). Indonesian Female Labor Migrants: Experiences Working Overseas. Jakarta: Indonesian Institute of Sciences

Robeyns, I. (2003). The capability approach: An interdisciplinary introduction. Netherlands: University of Amsterdam

Sabban, R. (2004). Women migrant domestic workers in the United Arab States. Geneva: ILO

Sabban \& Smith (2001). Women migrant domestic workers in the United Arab Emirates. The ILO publication

Satterthwaite, M. (2004). Intersecting protection, migrating women: Using human rights law to empower women migrant workers. Marginalization, Discrimination and Equality Series, 6, 542

Sen, A. (2005). Human rights and capabilities. Journal of Human Development, 6, 151-166

Silvey, R. (2004). Transnational migration and the gender politics of scale: Indonesian domestic workers in Saudi Arabia. Tropical Geography, 25, 141-155

Silvey, R. (2006). Consuming the transnational family: Indonesian migrant domestic workers to Saudi Arabia. Global Networks, 6, $23-40$

Varia, N. (2010).'Sweeping Changes?'A Review of Recent Reforms on Protections for Migrant Domestic Workers in Asia and the Middle East. New York: Human Right Watch

Yamanaka, K., \& Piper, N. (2005). Feminized migration in East and Southeast Asia: Policies, Actions and Empowerment. Geneva: United Nations Research Institute for Social Development

Yeoh, B.S.A., \& Annadhuri, K. (2008). Civil society and the creation of transformative spaces for migrant domestic workers in Singapore. Women's Studies, 37, 548-569

Williams, L., \& Labonte, R. (2007). Empowerment for migrant communities: Paradoxes for practitioners. Canada: Taylor and Francis. 